\title{
COOPERATIVES AND AGRICULTURE IN BUDDHISM
}

Shrestha, Kiran ${ }^{11}$

\begin{abstract}
Modern liberal economics is against the Buddhists economics. Unhealthy market competition, greed of money, top most professionalisms and economic depression and recessions are the dark side but reality of modern liberal economics. To avoid such negative consequences from livelihood, right livelihood, from a philosophy of noble eightfold path, Buddhists Economics will be a new dimension of new economic development. To check the current situation of Buddhists Economics in Nepalese Cooperatives and Agriculture a small literature review was conducted. From this review above specified hypothesis over the drawbacks of contemporary liberal economics have serious hegemony over small Nepalese Economy. Buddhists scholars must be able to impose the philosophy of Buddhists Economics in day to day life of people linked with business, production, cooperatives and agriculture.
\end{abstract}

Keywords: Agriculture, Buddhism, Cooperatives,

\section{Background}

The attitude of Lichhavi rulers towards Buddhism and them polices continued to play a prominent role in the development of Buddhism. It is supposedly called the golden age in the growth of Buddhist history in Nepal. The cooperative attitude of the Lichhavi rulers finally provided a basis for the overall development of Buddhism in ancient Nepal (Thapa, 2006). Buddhism is National religion of Nepal.

"Sangham Saranam Gachhami" is the supreme teaching of Gautam Buddha. Various scholars say that the Sangha is the group of hermits and monks- good people. The sangha is the community of monks and hermits to lead life of self-purity detachment and un responsive to wards temptation of senses. To make the life meaningful we must follow the good people. The people who know the real meaning of life and go through it are the good people. In the present context those people with common feeling of social welfare and community development are good people. They work for the betterment of their

${ }_{11}$ Mr. Shrestha is the PhD scholar of Lumbini Buddhists University and associated with SV Academy in Rural Development Email: kiransaritashrestha@gmail.com 
livelihood and far better on community works. Which group of contemporary worlds will be the perfect good community people? What is the livelihood reality of Sangha? Sangha is the community for cooperation. Those communities developed for cooperation is a cooperative. However, this competitive instinct can be redirected to induce cooperation.

One might unite the members of a particular group by inciting them to compete with another group. For example, corporate managers sometimes rally their employees to work together to beat their competitors. But this cooperation is based entirely on competition. Buddhism would call this "artificial cooperation (Payutto, 1992). True cooperation arises with the desire for well-being -- with chanda.

Human development demands that we understand how tanha and chanda motivate us and that we shift our energies from competition towards cooperative efforts to solve the problems facing the world and to realize a nobler goal (Payutto, 1992). From the different views of different scholars Buddhists Economics is different from western economics but we cannot ignore the western economics and its dominances. Adaptation of five Sila - percepts and eightfold path in human behavior deals with Buddhist Economics and differentiate it with western economics. Buddhists economics minimizes the risk and aggressive competition in market. It neutralizes the excessive competitions. So, it is the foundation of western economics.

(Different Characteristics of two economics prescribed by Laszlo Zsolnai)

\begin{tabular}{|l|l|}
\hline Western Economics & Buddhist Economics \\
\hline maximize profit & minimize suffering \\
\hline maximize desires & minimize desires \\
\hline maximize market & minimize violence \\
\hline maximize instrumental use & minimize instrumental use \\
\hline maximize self-interest & minimize self-interest \\
\hline "bigger is better" & "small is beautiful" \\
\hline "more is more" & "less is more" \\
\hline
\end{tabular}


(Payutto, 1992)

The economics are different and guided by different philosophies. If our life pattern is based on the philosophy of Buddha, it will be easy to follow Buddhists economics completely applied economics.

\section{Objectives}

Specifically, the objectives of the study can be summed up as

- To avoid negative consequences from livelihood, right livelihood, from a philosophy of noble eightfold path, Buddhists Economics will be a new dimension of new economic development.

- To check the current situation of Buddhists Economics in Nepalese Cooperatives and Agriculture a small literature review was conducted.

\section{Methodology}

The study is based on Literature review of Buddhist economy and contemporary capitalistic economy. The study compares the Buddhist economy and the sophisticated capitalistic theory of economy in cooperatives and agriculture.

\section{Discussion on Buddhists Economics}

The profounder of Buddhist religion, Gautama Buddha was born in Lumbini as Siddhartha Gautam from his Father King Suddhodan king of Shakya clan and Mother Queen Mayadevi in 491 BC. He got his enlightenment under a big banyan tree (Peepal) now known as Bodhi tree in Bodh Gaya India. Gautam Buddha is known as the Light of Asia. His teachings were mainly concentrated to make the world peaceful place to live with no killings which is also based on Panchasila Siddhanta. His sense of knowledge made him famous in entire Asia. So, he became a symbol of peace and eternity. Those five Sila-percepts are as below

- $\quad$ Do not take life

- Do not take what is not given 
- $\quad$ Do not distort facts

- Refrain from misuse of the senses

- Refrain from self-intoxication through alcohol or drugs (Bodhi, 1998).

Thus, human life is based on the reality of his noble eightfold path. Considered from the standpoint of practical training, the eight path factors divide into three groups: (i) the moral discipline group (Silak-khandha), made up of right speech, right action, and right livelihood; (ii) the concentration group (Samadhik-khandha), made up of right effort, right mindfulness, and right concentration; and (iii) the wisdom group (Paññak-khandha), made up of right view and right intention (Bodhi, 1998). Human life must go on the flow of happiness. The happiness is completely based on the teachings of lord Buddha and the philosophy.

The majority of Nepalese people depend on agriculture for their livelihoods. Hence, there is a high demand for agricultural resources such as inputs, seeds and fertilizers. Agricultural cooperatives are a crucial means by which to provide all the services needed by farmers under the same umbrella. It is therefore vital that agricultural cooperatives be managed effectively. Community is the integral part of the project as they are the key elements of the project operation and most importantly communities are the ones who benefit from the project's outcome. Community organization (CO) is small group of people in a community formed with a motive to carry out saving and credit activities within its members and assist in community development process. Some COs are officially registered and some act in informal ways. The development of multipurpose cooperatives was an act of shaping the sustainable future for the community organization in an institutional manner (Nepal, 2014). The long-term vision for cooperative development is to improve living standards of rural communities through collective institutional development. The cooperative therefore shall be a tool for recognition of COs, sustainability of developed infrastructure, and a focal point for availability of goods and services in a village (Nepal, 2014). Buddha's teaching formulated the economy in which the production of a country must be done not for oneself but for Ananta which also means that all the producers must make thing not limited to himself or herself. But he should produce grains or anything for other people living in the earth. This teaching also defines the love and togetherness and 
perfect harmony with all the people of the earth. In fact, in the $20^{\text {th }}$ century the development was defined as the economic growth of any nation.

As stated in the first desire that is Tanha there is the unhealthy competition of the things produced in the market. People have different types of desires the desires described in the first one is desire for enjoyment food for taste which lacks originality. So the factory and the industries want to make more and more goods and groceries and the products to sell in the market.

\section{Cooperatives}

A cooperative is an institution formed by a group of people in a society with a common motive to deal with their existing socio-economic problems. The universally accepted definition of a cooperative is given by the International Cooperative Alliance (ICA) in 2005, which states a cooperative as "An autonomous association of person united voluntarily to meet their common economic, social and cultural needs and aspirations through a jointly owned and democratically-controlled enterprise." (Nepal, 2014).

Buddhist teaching has always insisted about do not harm others and to make peace. Due to the unhealthy competition between the rich and poor countries there is the groupism between haves and have not People are rival to their profession. They are thirsty for the blood of each other. Thus, there is no good aim of life. Life is always in-between stress and strain. In contrary to this Buddhism teaches people for their well-being and spiritual development. Non-violence Not to harm any other animals and plants of the nature and. The lustful desire to be wealthy in no time will consequently lead them to the state of darkness. The spiritual world will lead them to the well-being of the flora and fauna of the world.

The enlighten of Buddha was obtained in Bodhgaya under a Peepal tree. So, the Buddhist religion teaches its monk to plant single tree by them everywhere. This will assist the earth for natural resource management. The developing countries like Nepal and other cannot compete the occidental countries which are very rich and have good GDP global domestic products. These countries have high growth and development in technology wealth resources. The production of their countries like technology software clothes arms and ammunitions are sold in the third countries and earn a lot of money. The developing 
countries have very low purchasing power and cannot afford them. So, there is the origination of dependency and political hegemony.

In the Buddhist countries like Bhutan, Burma, Thailand there is the concept of Global Happiness index. We can also adopt such policies. the lesson of nonviolence among the people as described by Buddhist teaching can endeavor the well-being of the people. People should be provided by guide training and tourism and hospitality. The tourist can have the spiritual knowledge and then enjoy out the natural beauty of the flora and fauna found in the Himalayas. The effective production and marketing of these agriculture products could bring significant change in economy from the individual household to the macro level. The lack of proper infrastructure and technology in the hilly and mountainous regions of Nepal is affecting the agriculture production in terms of input supply regarding e.g. agriculture tools, fertilizer etc. Even though the production is done, the goods fail to reach the market. Regardless of geography, the social and political factors and moreover the lack of knowledge or information flow between the producer and market unit are also affecting the marketing of products (Nepal, 2014). Buddhism lessons of eight-fold path and others as nonviolence has to be given to all the members of the cooperatives spread it in the country. The government can make policies and to development the tourism plans to guide the tourists in these agricultural places and the Buddhist sites for meditations. This assists to earn more revenue for the country. Cooperatives create significant potential for poverty reduction, employment opportunities, capacity building and empowerment through cost reduction, income generation, equal distribution of benefits, and sustaining business activities

Agriculture

Thus, Buddhist economists advocate ahimsa or non-violence. Ahimsa prevents doing anything that directly causes suffering to oneself or others and urges to find solutions in a participatory way. Community supported agriculture is one such example of communitybased economic activities. Buddhist economists believe that community-supported agriculture fosters trust; helps build value-based communities and brings people closer to the land and their food source. Achieving this sustainability and non-violence requires restructuring of dominating configurations of modern business, which they advocate. Sri Lankan economist Neville Karunatilake wrote that: "A Buddhist economic system has its 
foundations in the development of a co-operative and harmonious effort in group living. Selfishness and acquisitive pursuits have to be eliminated by developing man himself. Agriculture cooperatives can be categorized into three different forms: input supply, marketing, and production. The input supply cooperatives provide raw materials such as seeds, fertilizer, and livestock. Marketing cooperatives carry out distribution and finding places to sell the products, and the production cooperative does the final processing and makes the product high value for consumers (Nepal, 2014).

The above two definitions of cooperatives and agriculture can be adopted in order to make Nepal independent from any foreign imports. The government should emphasize in making university like Lumbini Buddhist University and others educational institute to carryout researches about applied Buddhism. One of them can be as stated below. In Nepal during the Lichhavi dynasty who follow Buddhism there was the Guthi system existed in which people of the same community or cast made a group who helped people of their circle in fest and festival death and sorrows which is also form of cooperative.

There are many places where the land is barren and cultivation is not carried out since many years. Besides these there are many landless people. The young generation have migrated to the foreign countries for earning money to feed their near and dear ones in the country. But the dream has not come true for the migrants as they have to face the Bottom Neck problem of migrations described by Michael Toddaro. This is only possible if the people can produce enough food nutrients as well as agricultural products and do not have to rely on other countries.

The government has to make some investments to the above areas and people who are deprived with wealth. the government has to facilitate the local cooperatives in cold storage building infrastructure, loan facilities and advertisement and marketing the modern farming has to be carried out through cooperatives. The cooperatives of people (farmers) have to be organized and hence they can be trained with modern farming system. The cash crops as cardamom, sugarcane cereals, corn paddy may be carried out. The crops thus produced can be distributed among all the members of the cooperatives. And the surplus can be sold to the market to buy the other needy things. 


\section{Conclusion}

In conclusion Cooperatives in agriculture should not just limited to saving and credit; they bear a lot of other socioeconomic responsibilities, that can be attained by the mobilization and mix up of Buddha's philosophy. Livelihood is one of the key sectors of human life and to make it sustainable, a cooperative has to play a major role. The roles are guided in Buddhism. As a result of the Right Livelihood initiative of the project, there are products available in the villages to sell. There has been a selling process but it has been totally unorganized. Thus, the cooperatives could act a marketing tool for agricultural products in the villages, which will ensure the sustainable future for both cooperatives and the farmers. However, in the western economics competition is high and Buddhists Economic Cooperation is high. All these cooperatives have key elements for marketing. Cooperatives run the collection center, they have market management committee, the products exist for selling, and modes of different kinds of transport. All the village products come to the collection center and then the cooperative distributes the products to various markets. The lack of knowledge, coordination, and support between the farmers and cooperatives is hindering the marketing activities. In the market of agricultural products, there exists competition. The competition must be transformed into cooperation. One is India, who is a big player in supplying cheap agricultural products to Nepal. The local village products may or may not compete with the big players, but the core idea is to develop the marketing practices in these villages. So, initiation has to be taken by cooperatives. Cooperatives must consider the matter of agriculture marketing seriously. Cooperatives are investing money for agriculture, and if the produced product fails to reach the market, a cooperative suffers from serious debt so it is necessary to adopt cooperative market rather than competitive. Small is beautiful.

\section{Reference}

Bodhi, V. (1998). The noble eightfold path : The Way to the End of Suffering. Bangkok: Buddhist Publication Society.

Nepal, A. (2014). Agriculture Marketing: a Sustainable Approach for Agricultural Cooperatives in the Far Western. Helsinki, Finland: Karelia University of applide 
Sciences.

Payutto, V. (1992). Buddhists Economics A Middle Way for the Market Place. Bangkok: Translated by Dhammavijaya and Bruce Evans.

Thapa, S. (2006). History of Nepalese Buddhism: From Mythological Tradition to the Lichhavi Period. Voice of History. 16. 10.3126/voh.v16i2.76., 25-42. 